\title{
猫の皮膚クリプトコッカス症の1例
}

\section{A Case of Feline Cutaneous Cryptococcosis}

\author{
末次文雄 $*$ 末次奈美 \\ マリアペットクリニック \\ Fumio Suetsugu*, Nami Suetsugu \\ Maria Pet Clinic
}

6 歳齢, 避妊雌, 体重 $3.6 \mathrm{~kg}$ の杂隹種猫が, 数日前か ら右胸部および後頭部の皮膚における隆起性病変, な らびにくしゃみを主訴に平成 21年 5 月 15 日に本院を 受診した。禀告によると, 症例は室内外を自由に出入 りしているとのことであつた。初診時，身体検査にお いて右胸部には波動感のある母指頭大の皮下結節を認 め, 結節の中央は潰痬化して排膿を認めた(Fig. 1)。ま た後頭部の皮膚には米粒大の丘疹か認められた。皮膚 病変を除いては, 身体検査上で特記すべき異常は認め られなかった。皮膚細菌感染症を疑い, オルビフロキ サシン $5 \mathrm{mg} \mathrm{kg}^{-1} \mathrm{q} 24 \mathrm{~h}$ を投与したものの, 臨床症状の 改善を認めなかった。乥こで初診時より7日目に, 胸 部の潰瘍部位から採取された膿汁の直接塗抹標本，な らびに後頭部皮下結節の針吸引生検材料について細胞 診を実施した。关の結果，いずれの試料からも萊膜を 有する円形の酵母樣真菌が多数見出され (Fig. 2), さ らに両試料の真菌培養検査 (株式会社 江東微生物研 究所) にて Cryptococcus neoformans が同定された。な お自験例では血清抗 FIV 抗体ならびに FeLV 抗原とも に陰性であり, 完全血球計算および血液生化学検査， ならびに胸部および頭部X線検査のいずれにおいても 異常は認められなかった。以上の結果より, 本症例を ネコの皮膚クリプトコッカス症と診断した。

自験例では, イトラコナゾール (イトリゾール , ヤ

*連絡先: 末次文雄 (マリアペットクリニック)

干 211-0015 神奈川県川崎市北谷町 103-3

TELFAX 044-555-3611

E-mail: poteji.suetsugu@ nifty.com

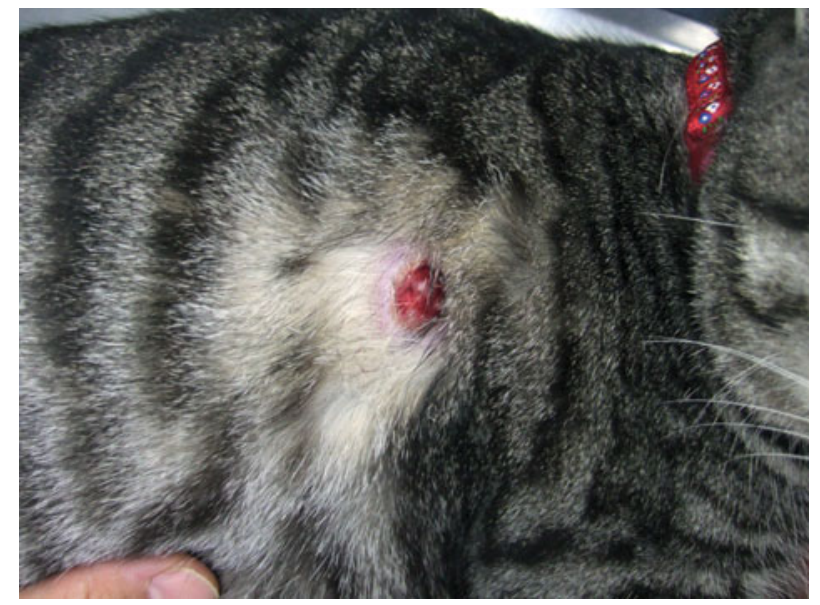

Fig. 1. Clinical findings of the cat. Ulceration and draining on a nodule are recognized on the lateral thorax.

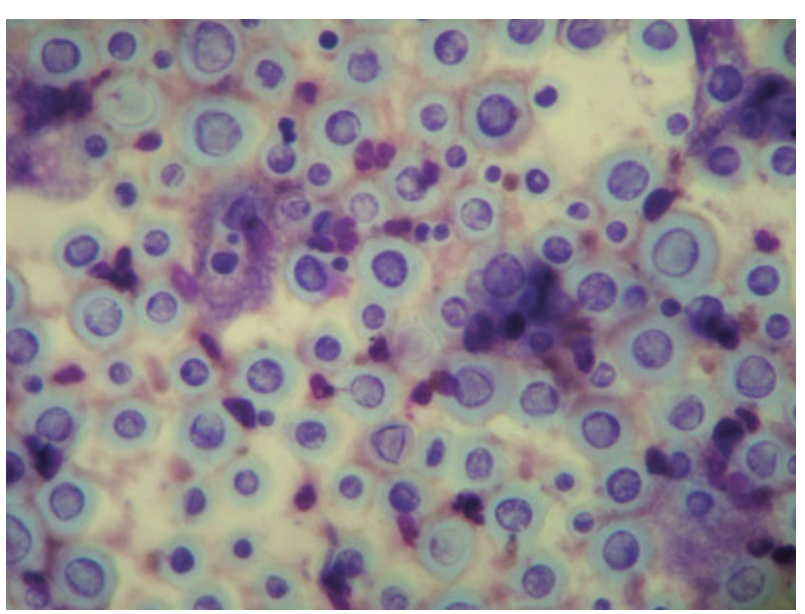

Fig. 2. Cytology shows capsulate yeasts with the small number of neutrophils or lymphocytes (WrightGiemsa's stain). 
ンセンファーマ株式会社, 東京) $5 \mathrm{mg} \mathrm{kg}^{-1} \mathrm{q} 24 \mathrm{~h}$ の内服 により加療した。光の結果，〈しゃみ症状は治療開始 後1週間で，また皮膚症状は約1カ月で消退したため治 療を終了した。現在は治療終了から 4カ月が経過する が，くしゃみおよび皮膚症状の再発は見られていな い。

クリプトコッカス症は, 萊膜を有する酵母樣真菌で あるCryptococcus neoformansによる感染症である。主 な感染源は鳩の粪，あるいは粪により污染された土㙥 であると考えられている。症例の多くでは菌に污染さ れた塵埃を吸引することで, まず呼吸器感染が成立す る。弚の後, 感染巣は血行性に多藏器に播種する場合 もある。一方で，無症状の犬の14\%，猫の7\%におい ても, 鼻腔内よりクリプトコッカスの菌体が検出され たとの報告がある1”。また，FeLVやFIVによる感染， あるいはグルココルチコイド製闵の長期投与などによ る免疫抑制状態が，本症の発症に関与することか指摘 されている1,2,4)。しかし自験例では，北宮らによる報 告例 ${ }^{3)}$ と同樣に , 一般状態ならびにウイルス検査も含 めた各種検査結果ともに異常は認められず，またグル
ココルチコイド製剂を含め先行する投薬歴も認められ なかった。このことから，免疫抑制状態が疑われない 猫においてもクリプトコッカス症が発症しうる可能性 が示唆されるとともに, 同症か鑑別診断に含まれる猫 に対しては積極的に細胞診を実施することが推奨され ると考えられた。

\section{引用文献}

1) Ettinger, S.J. and Feldman, E.C. 2000. pp. 468-471. In: Textbook of Veterinary Internal Medicine, 5th ed, W.B. Sanders, Philadelphia.

2) Gross, T.L., Ihrke, P.J., Walder, E.J. and Affolter, V.K. 2005. pp. 295-297. In: Skin Diseases of the Dog and Cat, Clinical and Histopathologic Diagnosis, 2nd ed, Blackwell Science, Oxford.

3) Kitayama-Munakata, E., Ando, J., Kano, R. and Nagata, M. 2007. Jpn. J. Vet. Dermatol. 13: 199-202.

4) Scott, D.W., Miller, W.H. and Griffin, G.E. 2001. pp. 395400. In: Small Animal Dermatology, 6th ed, W.B. Sanders, Philadelphia. 